\title{
Analysis of M42SP-7P on the Balinese Papyrus Script Printing System
}

\author{
Made Sudarma, Sri Ariyani \\ Department of Electrical and Computer Engineering, Faculty of Engineering, Udayana University, Indonesia
}

\begin{tabular}{l}
\hline Article Info \\
\hline Article history: \\
Received Jun 12, 2016 \\
Revised Aug 18, 2016 \\
Accepted Aug 29, 2016 \\
\hline
\end{tabular}

\section{Keyword:}

Control system

Papyrus

Printing control

Script printing

\begin{abstract}
Script writing art in the lives of Balinese people has a very important function, particularly in terms of writing a sacred script such as writing an inscription on copper plate, bronze, silver, and gold, by using a penknife which required a persistence, patience, skill and experience by itself, since not all Balinese people is able to do this very complicated work. Moreover, the Balinese papyrus is not only contains the text in Balinese script but also includes a dimensional drawing which is very complicated. Considering the difficulty in writing a script on papyrus and the rarity of script writer experts, therefore the researcher gives appreciation on papyrus preservation and conservation. In the present time, sophisticated technology has replaced manual equipments which required a lot of manpower to be operated. Maybe also the inscription writing model with ancient language and writing has been done so many times with computer technology by using the printer as the interface for printing. In this research, the Balinese script printing tools is designed namely a penknife using robotic technology which mimicking human hand's motion when writing a script on papyrus. Thought the script tool printer design through robotic technology in order to write a script on palm leaves is an important role of technology as an innovation strategy that is able to create new thinking, new ideas and inovation creative products. Eventually is also expected to satisfy the user as consumer and a new creative market.
\end{abstract}

Copyright $\odot 2016$ Institute of Advanced Engineering and Science. All rights reserved.

\section{Corresponding Author:}

Made Sudarma,

Departement of Electrical and Computer Engineering,

Faculty of Engineering,

Udayana University,

Jl. Tukad Yeh Aya, No. 46, Denpasar 80225, Bali, Indonesia.

Telp./Fax. +62361-230050

Email: imasudarma@gmail.com

\section{INTRODUCTION}

Various rescue and preservation attempts in general just touching the papyrus as literature/language work. There are lots of documents as the result of transliteration of papyrus literature content into various languages, but the research which peels out of papyrus fine arts aspect is still lacking. Fine arts or papyrus drawing is also need to be preserved by documenting and examining before the papyrus is destroyed because of aging[2]. The existence of papyrus script is not only concerning verbal aspect, but also visual aspect or papyrus fine arts. The ancestors of Balinese people were utilizing papyrus script not only as reading and writing media, but also designing it as the esthetic and functional "books". Both the exterior and the interior 
of papyrus were full of the fine arts touch starting from the manuscript format, technique of binding, material character, script and drawing format.

To write a script on the papyrus could take months, a papyrus script also required patience, persistence, and precision in order for the outcome script to be good as expected[8]. Every sheet of papyrus was given a line using the tool called panyipatan. Small ropes were spread on two bamboo spikes. Then underneath it was put the sheet of papyrus. The ropes then were given an ink and were pulled. The stretch of ropes which were pulled splashed the ink into the sheet of papyrus to form the lines. But now the process of line making on papyrus sheets was done using the pencil. So difficult is the process of writing on papyrus creating an anxiety of breaking the chain of continuity of script writer on papyrus. Young generation in the present time rarely has a desire to learn the writing on papyrus. In addition of the more advanced era, many of the young generation has an assumption that learning the writing on the papyrus is very difficult to be done since they have to mastering the skill of ancient language and writing.

From the exposure mentioned above, the researcher is trying to give an appreciation towards the preservation of the papyrus, by creating and implementing the intelligent penknife with technology basis in the process of papyrus writing. Intelligent penknife based on technology meant here is creating a robotic arm which can be controlled by computer system to write the papyrus mimicking human's natural intelligent[9]. Technology concept of pneumatic is very possible to perform the work with vector logic. In vector logic there also the process of papyrus writing horizontally and vertically and also able to perform the motion in the form of vector for each character [1]. Although the model of inscription writing with ancient language and writing has been done so many times with computer technology which is using printer interface as the printing tools, but all of it is still using paper media.

In this research we will design penknife tools with robotic technology which mimicking human arm's motion when writing a script and papyrus as physical printing media, so that the outcome product will benefit and able to preserve and establish the noble value of local culture wisdom. In addition it can open work opportunity for traditional penknife operators to become modern penknife operators and improve their economic lives. The success factor of using technology innovation is a creativity requiring, which is one business capabilities [5]. In developving of innovation technology is an essential and great idea in producing a unique and superior products to be compete. Moreover, the opening of creative market it will impact positively on the performance of marketing [10]. Even it can also improve populist economic system for creative business in Bali. Other contribution is expected to provide alternative solution to overcome the limitation of experienced experts of papyrus writers. It is in fact can contribute to the preservation of local wisdom. The success of this research implementation can also provide unlimited added value for Balinese society in particular and Indonesian people in general.

\section{RESEARCH METHOD}

This research consists of several steps, those are literature study, design and construction of papyrus printing, construction of stepper motor driver, program development for device system through computer, and analysis of system output. The first step performed in this research is to see the specification of stepper motor being used then to carry out the design and construction of that stepper motor specification, after that the developing of programming language necessary for operating motor driver being built. Further the manipulator and control system being built is tested for its function and working system by way of measuring the stress precision arising from the process occurred because of the motion of stepper motor on the manipulator of printing device. Penknife using robotic technology will improve the competitiveness of products, thus the continuous innovation of technology allows opening a new business venture for the users and improve the economy of Bali community.

\subsection{The Construction of Stepper Motor Control System}

There are several criteria which needed an attention from stepper motor specification, among others: torque, power, dimension, and the speed of motor response[7]. Those things should be noted since it is being used at the time of conducting the calculation and analysis. Stepper motor is a DC motor which is widely used on robotic system because of its advantage in position accuracy level and can rotate towards intended direction only by giving an electric pulse with certain patterns. The rotation occurred when the rotor gears pulled by stator poles which is magnetized[3]. The following Figure 1 shows the construction and way of working of stepper motor.

If the pulse is given from first phase to fourth phase then stepper motor is rotating clockwise and if given the reverse pulse then the stepper motor will rotate counter clockwise[4]. In Figure 2 it shows the stepper motor driver sequences which is generally used for interface process of stepper motor with parallel ports.

IJRA Vol. 5, No. 3, September 2016: 199 - 204 


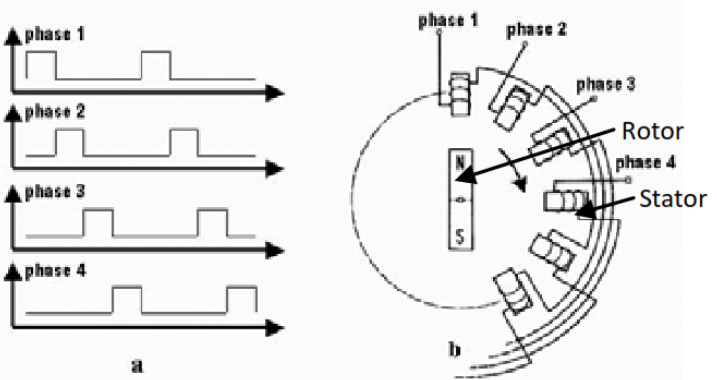

Figure 1. Cross-section of the stepper motor

In this research, the scheme of control system circuit of stepper motor being used consists of several components of basic electronic, that is resistor, transistor, and diode. It is performed in order to be known the function performance of each component. Several control system circuits required among others: stepper motor pulse generator circuit, stepper motor circuit, and stepper motor address circuit which will be driven. The complementary device of robotic arm driver consists of power supply with constant DC voltage of 24 Volt (power supply on the printer) and 25-pin parallel port connectors (DB-25). The function of parallel port is as communication controller. Electric specification for parallel port, namely Logical "1" (high) is the voltage of +2.4 up to $+5 \mathrm{~V}$ and Logical " 0 " is voltage 0 up to $+0.8 \mathrm{~V}$.

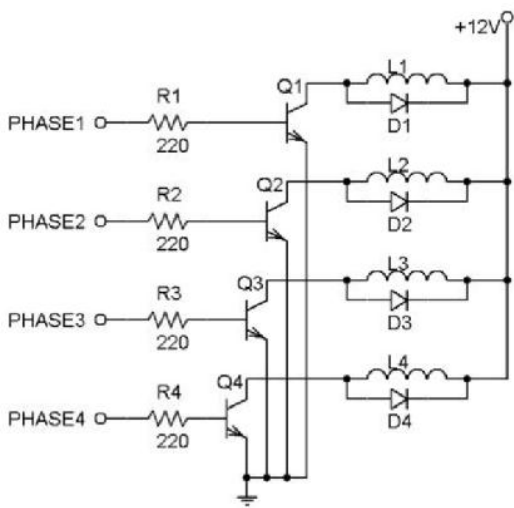

Figure 2. Stepper motor driver circuit

\subsection{Control System Programming}

The interface of robotic control system in general is electronic circuit based on microprocessor which has a function as the controller of electronic components in establishing working function of the system, which in this activity it is performed directly by the computer. The main function of control system being constructed, that is by starting and finishing the movement of manipulator components in the intended stage with specific point, storing position data and also stage data in the database, and allowing the robot to be able to perform interfacing with certain devices[5].

The process of control system is derived from the program developed in one computer unit. Input data which is being used to control the movement is according to its function. The occurrence of task changing is processed through programming language logic, next the data is sent by computer to motor driver circuit through parallel port communication system. Next after the data is received by driver circuit, then the data will be processed to produce signal (electric current) in order to operate the stepper motor[7].

\section{RESULTS AND ANALYSIS}

The experiment conducted to find out of the tool level precision and the errors occurred on the tools. After the construction, the test and measurement are performed on the device for its ability to lift up, shift, and the papyrus movement. Moreover, in the minimal scale is obtained to become the specification reference of the whole ability device. Figure 3 is presented the design of papyrus printing device with stepper motor control system. 


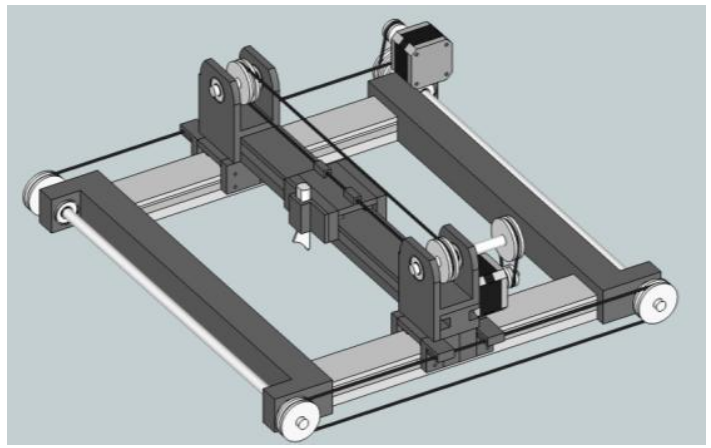

Figure 3. Design of papyrus printer with M42SP-7P control system

The following outcome result analysis of M42SP-7P testing which is being used in designing and construction of Balinese papyrus script printing device as follows:

a. Power supply voltage

The condition of power supply voltage is measured at the point of:

- $\quad$ Non load voltage of $20.97 \mathrm{~V}$

- Full load voltage of $19.95 \mathrm{~V}$.

From the outcome the voltage deviation is measured:

$$
\begin{aligned}
& =\left\{\frac{V_{\text {non_load }}-V_{\text {full_load }}}{V_{\text {non_load }}}\right\} \times 100 \% \\
& =\left\{\frac{20,97-19,95}{20,97}\right\} \times 100 \%=4,86 \%
\end{aligned}
$$

Voltage deviation of power supply at $4.86 \%$ is still below the standard allowed, so that it can be concluded that power supply circuit can work well.

\section{b. Parallel-port communication voltage}

The condition of power supply voltage is measured at the point of:

- Logical voltage of " 0 " (low) $=0.2 \mathrm{~V}$

- Logical voltage of " 1 " (high) $=4.48 \mathrm{~V}$

From the result of parallel port voltage measurement is obtained that the voltage value of logical 0 and logical 1 is in normal limit, that is logical 0 is in the range of 0 up to $0.8 \mathrm{~V}$ and logical 1 is in the range of 2.4 up to $5 \mathrm{~V}$. So that it can be concluded that parallel port can work well.

\section{c. Driver circuit voltage}

The voltage condition from the test result is as follows:

- Closed switch (saturation) is $0 \mathrm{~V}$

- Open switch (cut-off) is $20.8 \mathrm{~V}$

- Input voltage switch (Vin) is $21.34 \mathrm{~V}$

Driver voltage deviation:

$$
\begin{aligned}
& =\left\{\frac{V_{\text {in }}-V_{\text {cut }- \text { off }}}{V_{\text {cut }- \text { off }}}\right\} \times 100 \% \\
& =\left\{\frac{21,34-20,8}{20,8}\right\} \times 100 \%=2,58 \%
\end{aligned}
$$

The deviation of driver voltage at $2.58 \%$ is less value than $5 \%$, so that it can be concluded that the circuit can work well.

\section{d. The result of loading ability}

The printer testing results of load capability shown as the following table: 


\begin{tabular}{ll}
\hline Testing Field & Testing Result \\
\hline Stepper Motor Torque & $51.9 \mathrm{~N} . \mathrm{mm}$ \\
Torque after reduction & 70.9 N.mm \\
Load Lift Estimation (EAB) & $0.25 \mathrm{~kg}$ \\
Load Lift Ability (KAB) & $0.19 \mathrm{~kg}$ \\
\hline
\end{tabular}

The analysis of loading deviation is:

$$
\begin{aligned}
& =\left[\frac{E A B-K A B}{E A B}\right] \times 100 \% \\
& =\left[\frac{0,25-0,19}{0,25}\right] \times 100 \%=24 \%
\end{aligned}
$$

The deviation of $24 \%$ shows that there is a loss occurred in printing device manipulator transmission system and input voltage on stepper motor driver circuit is not supplied optimally.

\section{CONCLUSION}

The results of M42SP-7P of papyrus printing which is using stepper motor control system in the deviation cumulatively, it means that there is no correction process on the resulted errors. It is also affected by the hardware of stepper motor driver circuit which is communicated with the computer that has limitation of parallel communication slots. The deviation of power supply voltage at $4.86 \%$ has a meaning that power supply circuit for stepper motor can work well. Similarly there is a deviation of driver voltage at $2.58 \%$ which the value is less than $5 \%$, can have a meaning that the circuit also can work well. Furthermore, the analysis result of load ability deviation of printing field is $24 \%$, it shows that there is a loss occurred on papyrus printing device manipulator transmission system, so that the power of stepper motor is not optimal. Therefore it is necessary to do an improvement on the design of stepper motor driver circuit.

\section{ACKNOWLEDGEMENTS}

The appreciation is awarded to the Department of Electrical and Computer Engineering, Fculty of Engineering Udayana University which has supported in lending the equipments and instrumentation laboratory in this research.

\section{REFERENCES}

[1] Bradley J. T., et.al., 2008, Extracting Scientific Results from Robotic Arm Support Operations : A Technique for Estimating the Density and Composition of Rocks on Mars, The International Journal of Mars Science and Exploration, Mars 4, \# 27-32.

[2] Herman, V.J., dkk. , 1993. Petunjuk Teknis Perawatan Naskah Lontar. Pembinaan permuseuman Nusa Tenggara Barat.

[3] Mayoowari, R.T., 2004, Perancangan Sistem Pengatur Kamera Dengan Motor Stepper Yang Berbasis Komputer. Universitas Sriwijaya. \#1-8

[4] Pitoworno Endra., 2006, Robotika: Desain,Kontrol, dan Kecerdasan Buatan. Yogyakarta: ANDI OFFSET (Penerbit ANDI).

[5] Rashidifar,MA., et.al., 2013, Modeling and Control of 5DOF Robot Arm Using Fuzzy Logic Supervisory Control, International Journal of Robotics and Automation (IJRA) Vol. 2, No. 2, June 2013, pp. 56 68, ISSN: 2089-4856

[6] Rechay I. et al., 2012, The Role of Knowledge Sharing in Raising the Task Innovativeness of System Analyst, International Journal of Knowledge Management., Vol.8, No.2. \#1-22.

[7] Saputra, H.M., 2010, Rancang Bangun Sistem Kendali Motor Stepper Printer Canon BJC-S200SPx untuk Prototipe Lengan Robot 5-DOF (Majabot), INKOM Vol. IV No. 1 Mei 2010

[8] Sudarma, Made, 2014, Transkripsi wawancara dengan penulis lontar: I Wayan Muditadana (Desa Tenganan, Februari 2014), dan I Wayan Tusan (Br. Tinggah, Dusun Pande Sari, Bebandem, Maret 2014), unpublished 
[9] Sudarma, Made., 2011, Kecerdasan Buatan (Artificial Intteligent), Udayana University Press, ISBN: 978-979-8286-71-6

[10] Teece and Pisano, 2001, Developing Innovation Capability in Organization : Dynamic Capability Approach., Benn Lowson Danny Samson

\section{BIOGRAPHIES OF AUTHORS}

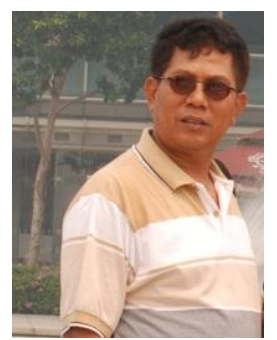

Dr. Ir. Made Sudarma, M.A.Sc.

Department of Electrical and Computer Engineering

Engineering Faculty, Udayana University

Bukit Jimbaran, Bali, Indonesia

Tel./Fax : +62361703315

e-mail: imasudarma@gmail.com

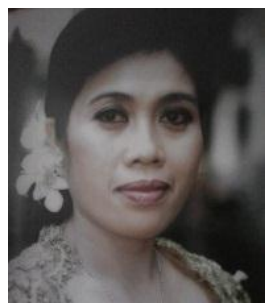

Dr. Ir. Ni Wayan Sri Ariyani, MM.

Department of Electrical and Computer Engineering

Engineering Faculty, Udayana University

Bukit Jimbaran, Bali, Indonesia

Tel./Fax : +62361703315

e-mail: sriariyani@unud.ac.id 